\title{
Autosomal dominant transmission of transient neonatal lactic acidosis: a case report
}

\author{
Emily B. Mardian ${ }^{1}$, Matthew A. Lines ${ }^{1,2}$, Care4Rare Consortium ${ }^{3}$ and Gregory P. Moore ${ }^{1,3,4,5^{*}}$
}

\begin{abstract}
Background: Lactic acidosis is a common finding in neonates, in whom mitochondrial dysfunction is often secondary to tissue hypoperfusion, respiratory failure, and/or sepsis. Primary (non-physiological) lactic acidosis is comparatively rare, and suggests the presence of an inborn error of mitochondrial energy metabolism. Optimal medical management and accurate prognostication requires the correct determination of the etiology of lactic acidosis in a given patient. Unfortunately, genetic diagnoses are rare and highly variable for neonates presenting with primary lactic acidosis; individual case reports may offer the most promise for treatment considerations. The mitochondrion is a complex molecular machine incorporating the products of $>1000$ distinct nuclear genes. Primary lactic acidoses are therefore characterized by high genetic heterogeneity and a specific genetic diagnosis currently remains out of reach in most cases. Most mitochondriopathies with neonatal onset follow autosomal recessive inheritance and carry a poor prognosis. Here we detail the case of a father and daughter with dominantly-inherited, resolving (i.e. transient) neonatal hyperlactatemia due to complex IV deficiency. We found no other published descriptions of benign transient complex IV deficiency with autosomal dominant inheritance.
\end{abstract}

Case presentation: Both individuals presented as neonates with unexplained, marked lactic acidosis suggesting a primary mitochondrial disorder. Within the first weeks of life, elevated blood lactate levels normalized. Their clinical and developmental outcomes were normal. Biochemical studies in the proband showed multiple abnormalities consistent with a complex IV respiratory chain defect. Cultured skin fibroblasts showed an elevated lactate-topyruvate ratio, deficient complex IV activity, and normal pyruvate dehydrogenase and pyruvate carboxylase activities. Whole-exome sequencing of the proband and both parents did not identify a causative mutation.

Conclusion: We conclude that the proband and her father appear to have a dominant form of transient neonatal hyperlactatemia due to heterozygous changes in an as-yet unidentified gene. This transient neonatal complex IV deficiency should be considered in the differential diagnosis of primary neonatal hyperlactatemia; notable clinical features include autosomal-dominant inheritance and an apparently benign postnatal course. This report exemplifies the growing differential diagnosis for neonatal lactic acidosis and highlights the importance of both physician counselling and the use of family history in communicating with parents.

Keywords: Primary lactic acidosis, Transient lactic acidosis, Inborn errors of metabolism, Neonate

\footnotetext{
* Correspondence: gmoore@cheo.on.ca

${ }^{1}$ Faculty of Medicine, University of Ottawa, Ottawa, Ontario, Canada

${ }^{3}$ Children's Hospital of Eastern Ontario Research Institute, Ottawa, Ontario, Canada

Full list of author information is available at the end of the article
}

(c) The Author(s). 2020 Open Access This article is licensed under a Creative Commons Attribution 4.0 International License, which permits use, sharing, adaptation, distribution and reproduction in any medium or format, as long as you give appropriate credit to the original author(s) and the source, provide a link to the Creative Commons licence, and indicate if changes were made. The images or other third party material in this article are included in the article's Creative Commons. licence, unless indicated otherwise in a credit line to the material. If material is not included in the article's Creative Commons licence and your intended use is not permitted by statutory regulation or exceeds the permitted use, you will need to obtain permission directly from the copyright holder. To view a copy of this licence, visit http://creativecommons.org/licenses/by/4.0/ The Creative Commons Public Domain Dedication waiver (http://creativecommons.org/publicdomain/zero/1.0/) applies to the data made available in this article, unless otherwise stated in a credit line to the data. 


\section{Background}

Lactic acid is an anaerobic metabolite that tends to accumulate whenever cellular respiration is inadequate to meet cellular energy requirements. Commonly, lactic acidosis reflects acquired mitochondrial dysfunction due to impaired tissue oxygenation ('shock'). In neonates, hyperlactatemia is commonly observed in sepsis, hypoxic-ischemic injury, and congenital heart disease. When secondary, blood lactate levels mirror the patient's clinical state, resolving with correction of the underlying disease process [1]. Primary lactic acidosis that is inappropriate to the clinical context suggests an inborn error of cellular energy metabolism. Collectively, these primary lactic acidoses are numerous. They are genetically heterogeneous with disorders of mitochondrial oxidative phosphorylation or pyruvate metabolism accounting for most cases. Because the mitochondrion is complex, comprising the products of $>1000$ distinct nuclear genes, genetic diagnosis of primary mitochondrial disorders is rarely found, occurring only in $\sim 25-50 \%$ of cases [2, 3]. With few exceptions (e.g. holocarboxylase synthetase deficiency, which is treatable with biotin, and pyruvate dehydrogenase deficiency, which is somewhat treatable with the ketogenic diet), specific treatments are lacking, and many patients die in infancy or childhood [4]. Here we detail the case of a father and daughter with dominantly-inherited, resolving (i.e. transient) neonatal hyperlactatemia due to transient complex IV deficiency. No previous description of such an autosomal dominant form of benign, transient complex IV appears to exist in the literature; this reiterates the increasing differential diagnosis for lactic acidosis in a neonate.

\section{Case presentation}

Ethics approval and consent to participate

Given this was a case report, the Children's Hospital of Eastern Ontario Research Ethics Board did not need to approve the work, as per their regulations. The parents provided written consent for their daughter's clinical information to be disseminated as a case report.

\section{Patient information}

A newborn female was born at $40+3$ weeks gestation (birth weight $3117 \mathrm{~g}$ ) after a vacuum-assisted delivery secondary to fetal decelerations and failure to progress following an otherwise uncomplicated pregnancy. Apgar scores were 7 and 8 at 1 and $5 \mathrm{~min}$, respectively. She had ongoing mild hypoglycemia and temperature instability over her first $18 \mathrm{~h}$ resulting in admission to the Neonatal Intensive Care Unit. She then developed moderate respiratory distress and regurgitation of feeds.

\section{Clinical findings}

Arterial bloodwork at $19 \mathrm{~h}$ of life revealed: serum lactate $19.8 \mathrm{mmol} / \mathrm{L}$ (Reference interval [RI]: <2.2 mmol/L), $\mathrm{pH}$ 7.26, $\mathrm{p}_{\mathrm{a}} \mathrm{CO}_{2} 12 \mathrm{mmHg}, \mathrm{p}_{\mathrm{a}} \mathrm{O}_{2} 131 \mathrm{mmHg}$, bicarbonate 5 $\mathrm{mmol} / \mathrm{L}$, and elevated transaminases (AST $243 \mathrm{U} / \mathrm{L}$, ALT $54 \mathrm{U} / \mathrm{L})$ and alkaline phosphatase (333 U/L). At 24 $\mathrm{h}$ of life, thiamine (100 mg every $12 \mathrm{~h}$ ) and biotin $(8 \mathrm{mg}$ every $12 \mathrm{~h}$ ) were initiated via nasogastric tube and continued for 4 days. Over the following $24 \mathrm{~h}$, the elevated lactate levels, hypoglycemia, and respiratory distress progressively improved with resulting clinical stability. An echocardiogram and serum creatinine kinase were normal. The patient had routine metabolic studies performed at $21 \mathrm{~h}$ of life. Plasma amino acids showed several abnormalities including increased alanine $(936 \mu \mathrm{mol} / \mathrm{L} ;$ RI $131-710)$, proline $(1001 \mu \mathrm{mol} / \mathrm{L} ; \quad \mathrm{RI}$ 110-417), glutamine $(946 \mu \mathrm{mol} / \mathrm{L} ;$ RI 376-709), and tyrosine $(396 \mu \mathrm{mol} / \mathrm{L}$; RI 55-147), consistent with mitochondrial and hepatic dysfunction. Urine organic acids showed increased excretion of lactic acid and tyrosine metabolites (the latter being a non-specific indication of liver dysfunction). Acylcarnitine profile showed increased glutarylcarnitine $(0.29 \mu \mathrm{mol} / \mathrm{L}$; RI 0.25$)$ and multiple long chain acylcarnitine species. Muscle biopsy was deferred given the patient's clinical improvement. Cultured skin fibroblasts exhibited normal pyruvate dehydrogenase and pyruvate carboxylase activities, a markedly elevated lactate:pyruvate ratio (59.66, RI 10$25)$ and reduced complex IV activity $(2.69 \mathrm{nmol} / \mathrm{min} / \mathrm{mg}$ protein, RI 4-12). The patient was discharged home at 7 days of life after all clinical concerns had resolved several days prior.

\section{Follow-up}

The patient's clinical and laboratory findings were not in keeping with holocarboyxlase synthetase deficiency, and biotin was discontinued after 4 days of treatment. Thiamine was also simultaneously discontinued with no observable effect on the blood lactate level. The blood lactate level remained only mildly elevated (3-4 mmol/ $\mathrm{L})$, as did the AST and ALT prior to discharge. All of these had normalized by follow-up at 6 months of age. At 10 months follow-up, physical examination and blood results were normal. The patient met all expected developmental, gross motor, fine motor, and language milestones.

\section{Family history}

Records were sought regarding the patient's father, who had a similar presentation 32 years prior. He was born at 39 weeks gestation and weighing $3620 \mathrm{~g}$ following an uneventful delivery with Apgars of 9 and 10 at 1 and 5 min, respectively. At $12 \mathrm{~h}$, he presented with respiratory distress following feeding and blood work showed an 
elevated serum lactate of $4.8 \mathrm{mmol} / \mathrm{L}, \mathrm{pH} 7.34, \mathrm{pCO} 228$ $\mathrm{mmHg}$, and bicarbonate $15 \mathrm{mmol} / \mathrm{L}$. Lactate levels normalized after a $36 \mathrm{~h}$ fast. Plasma amino acids showed multiple elevations including alanine $(648 \mu \mathrm{mol} / \mathrm{L}$; RI < $345)$, glycine $(433 \mu \mathrm{mol} / \mathrm{L} ; \mathrm{RI}<248)$, and ornithine $(171 \mu \mathrm{mol} / \mathrm{L} ;$ RI $<61)$. He received a low-fat, highcarbohydrate diet for 4 months. Metabolic testing in cultured skin fibroblasts was normal (detailed records unavailable) and no diagnosis was made.

\section{Outcomes}

The observed father-daughter transmission of the phenotype in this kindred was potentially compatible with autosomal dominant (or, less likely, X-linked dominant) inheritance but not with matrilineal (mtDNAbased) inheritance. To study the genetic etiology of the primary lactic acidosis in this kindred, whole-exome sequencing (WES) of the proband and both parents was performed on a research basis (Care4Rare Consortium) after appropriate consents were obtained. Research by the Care4Rare Consortium was approved by the Children's Hospital of Eastern Ontario Research Institute Research Ethics Board (ref \#11/04E). The genomic analysis did not identify any pathogenic, likely-pathogenic or compelling candidate variant(s) to account for the clinical phenotype in the family. Specifically, no pathogenic or likely-pathogenic variants were detected in TRMU (mitochondrial tRNA modifying enzyme).

\section{Discussion and conclusions}

We describe a father and daughter with transient neonatal lactic acidosis, mild transient hepatic dysfunction, spontaneous clinical resolution, and no apparent developmental sequelae. Complex IV activity and lactate: pyruvate ratio were markedly abnormal in skin fibroblasts derived from the daughter. This disorder appears to represent an autosomal dominant (or, less likely, Xlinked-dominant) form of transient complex IV deficiency caused by mutation of an as-yet unidentified nuclear gene.

Mitochondrial disorders are among the most common and heterogeneous inherited metabolic diseases in humans, with >185 known (and several hundred unknown) genetic types [5, 6]. Inheritance is commonly autosomal recessive or maternal, but may be autosomal dominant or X-linked. Although most mitochondrial disorders are permanent (non-remitting), several previous papers do describe reversible infantile respiratory chain defects. They report their patients having neonatal or infantile presentations lasting weeks to months (e.g. one or more of hypotonia, liver failure, prolonged feeding difficulties, or respiratory insufficiency) with or without later sequelae such as feeding intolerance, hypotonia, hepatopathy, respiratory weakness, or motor delays in the context of a persisting myopathy [7-9]. In contrast, the individuals presented in this report had both a relatively benign neonatal presentation and an apparently normal clinical outcome. Complex IV deficiency states are themselves genetically heterogeneous, with at least 20 distinct genetic causes [10]. Most pediatriconset complex IV disorders are recessive, life-limiting conditions affecting the brain, cardiac muscle, liver, and other essential body systems. Although we are aware of a dominant form of $\mathrm{SCO} 2$ deficiency associated with severe myopia [11], and a matrilineally-inherited benign transient form caused by $\mathrm{m} .14674 \mathrm{~T}>\mathrm{C}$ homoplasmy [8], we are not aware of any other published descriptions of benign transient complex IV deficiency with autosomal dominant inheritance.

Although rapidly becoming the first-line diagnostic test of choice for suspected mitochondrial disorders, WES results in a high-probability gene assignment in < $1 / 3$ of individuals tested $[12,13]$. This is in accord with the general WES-associated molecular diagnostic rate of 20-30\% for other unsolved Mendelian disorders [14, 15]. Potential reasons for the modest molecular diagnostic rate are manifold. At present, we are aware of only 6000 human disease genes, and we suspect that there are many more with estimates of 6000-13,000 disease genes yet to be identified [16]. Furthermore, the variation responsible for the transient lactic acidosis may not be detectable by "exon" level methods such as variation in the non-coding region, a chromosomal deletion or $\mathrm{du}$ plication, complex chromosomal rearrangement(s) or expansion mutations. Technological advances such as whole-genome sequencing and RNA-Seq may resolve some of these issues and provide answers for the family in the near future.

The transient disorder described in this report should be considered a rare exception to the poor prognosis characteristic of most primary lactic acidoses [17]. In the absence of an accurate clinical and family history, transient primary hyperlactatemia may easily be mistaken for typical etiologies of lactic acidosis such as sepsis, congenital heart disease, and perinatal hypoxic-ischemic injury. Although uncommon, the condition presented here should be considered when counseling parents of neonates with primary lactic acidosis regarding prognosis. This case report emphasizes how the incorporation of parents, and their family history, may be vital to providing the most comprehensive overview of the neonate's status and potential prognosis. Physicians also need to have this transient primary lactic acidosis on their differential diagnosis. While providing general supportive treatment for a primary lactic acidosis (e.g. vitamins that act as cofactors and antioxidants directed towards specific signs and symptoms), physicians can cautiously note to parents that their neonate may have a transient 
benign form of the clinical condition. Future genetic counselling and prenatal advice could prove useful for families as well [17]. Genetic counselling for inborn errors of metabolism varies by etiology, with this case presenting as an apparently dominant form resulting in a $50 \%$ chance of recurrence. Limitations for this case report include the need for future research required to elucidate the causative mutation and pathophysiology.

\section{Abbreviations}

RI: Reference interval; WES: Whole-exome sequencing

\section{Acknowledgements}

Not applicable.

\section{Authors' contributions}

GM and ML were involved in the conception and design of the manuscript and critically revised all elements. EBM reviewed the literature and drafted the manuscript. Care4Rare Consortium performed and analyzed the wholeexome sequencing. All authors (with Dr. David Dyment representing the Care4Rare Consortium) read and approved the final manuscript.

\section{Funding}

Not applicable.

\section{Availability of data and materials}

Not applicable.

\section{Ethics approval and consent to participate}

Not applicable.

\section{Consent for publication}

Written informed consent was obtained by the adult patient and by both parents of the patient under 18 years of age.

\section{Competing interests}

The authors declare that they have no competing interests.

\section{Author details}

${ }^{1}$ Faculty of Medicine, University of Ottawa, Ottawa, Ontario, Canada. ${ }^{2}$ Division of Metabolics and Newborn Screening, Department of Pediatrics, Children's Hospital of Eastern Ontario, Ottawa, Ontario, Canada. ${ }^{3}$ Children's Hospital of Eastern Ontario Research Institute, Ottawa, Ontario, Canada. ${ }^{4}$ Division of Neonatology, Department of Pediatrics, Children's Hospital of Eastern Ontario, Ottawa, Ontario, Canada. ${ }^{5}$ Division of Newborn Care, Department of Obstetrics and Gynaecology, The Ottawa Hospital-General Campus, Box 806, 401 Smyth Road, Ottawa, Ontario K1H 8L1, Canada.

Received: 11 October 2019 Accepted: 15 April 2020

Published online: 20 April 2020

\section{References}

1. Walter JH. Metabolic acidosis in newborn infants. Arch Dis Child. 1992;67(7 Spec):767-9.

2. Calvo SE, Compton AG, Hershman SG, Lim SC, Lieber DS, Tucker EJ, et al. Molecular diagnosis of infantile mitochondrial disease with targeted nextgeneration sequencing. Sci Transl Med. 2012;4(118):118ra10

3. Pagliarini DJ, Calvo SE, Chang B, Sheth SA, Vafai SB, Ong SE, et al. A mitochondrial protein compendium elucidates complex I disease biology. Cell. 2008;134(1):112-23.

4. Debray FG, Lambert M, Chevalier I, Robitaille Y, Decarie JC, Shoubridge EA et al. Long-term outcome and clinical spectrum of 73 pediatric patients with mitochondrial diseases. Pediatrics. 2007:119(4):722-33.

5. Schaefer AM, McFarland R, Blakely EL, He L, Whittaker RG, Taylor RW, et al. Prevalence of mitochondrial DNA disease in adults. Ann Neurol. 2008;63(1): 35-9.

6. Vafai SB, Mootha VK. Mitochondrial disorders as windows into an ancient organelle. Nature. 2012;491(7424):374-83.
7. Uusimaa J, Jungbluth H, Fratter C, Crisponi G, Feng L, Zeviani M, et al. Reversible infantile respiratory chain deficiency is a unique genetically heterogenous mitochondrial disease. J Med Genet. 2011;48(1):660-8.

8. Horvath R, Kemp JP, Tuppen HA, Hudson G, Oldfors A, Marie SK, et al. Molecular basis of infantile reversible cytochrome c oxidase deficiency myopathy. Brain. 2009;132(11):3165-74.

9. Low E, Crushell EB, Harty SB, Ryan SP, Treacy EP. Reversible multiorgan system involvement in a neonate with complex IV deficiency. Pediatr Neurol. 2008:39(5):368-70.

10. Rak M, Benit P, Chretien D, Bouchereau J, Schiff M, El-Khoury R, et al. Mitochondrial cytochrome c oxidase deficiency. Clin Sci. 2016;130(6):393407.

11. Tran-Viet KN, Powell C, Barathi VA, Klemm T, Maurer-Stroh S, Limviphuvadh $\mathrm{V}$, et al. Mutations in $\mathrm{SCO} 2$ are associated with autosomal-dominant highgrade myopia. Am J Hum Genet. 2013:92(5):820-6.

12. Kohda M, Tokuzawa Y, Kishita Y, Nyuzuki H, Moriyama Y, Mizuno Y, et al. A comprehensive genomic analysis reveals the genetic landscape of mitochondrial respiratory chain complex deficiencies. PLoS Genet. 2016 12(1):e1005679.

13. Lieber DS, Calvo SE, Shanahan K, Slate NG, Liu S, Hershman SG, et al. Targeted exome sequencing of suspected mitochondrial disorders. Neurology. 2013;80(19):1762-70

14. Yang Y, Muzny DM, Xia F, Niu Z, Person R, Ding Y, et al. Molecular findings among patients referred for clinical whole-exome sequencing. JAMA. 2014; 70(3):164-7.

15. Lee H, Deignan لـ, Dorrani N, Strom SP, Kantarci S, Quintero-Rivera F, et al. Clinical exome sequencing for genetic identification of rare Mendelian disorders. JAMA. 2015:312(18):1880

16. Bamshad MJ, Nickerson DA, Chong JX. Mendelian gene discovery: fast and furious with no end in sight. Am J Hum Genet. 2019;105(3):448-55.

17. Ganetzky RD, Cuddapah SR. Neonatal lactic acidosis: a diagnostic and therapeutic approach. NeoReviews. 2017;18(4):e217-27.

\section{Publisher's Note}

Springer Nature remains neutral with regard to jurisdictional claims in published maps and institutional affiliations.

\section{Ready to submit your research? Choose BMC and benefit from:}

- fast, convenient online submission

- thorough peer review by experienced researchers in your field

- rapid publication on acceptance

- support for research data, including large and complex data types

- gold Open Access which fosters wider collaboration and increased citations

- maximum visibility for your research: over $100 \mathrm{M}$ website views per year

At BMC, research is always in progress.

Learn more biomedcentral.com/submission 